\title{
Evaluation of morphology, productive potential and oil content and composition of plant genetic resources of Camelina sativa
}

\author{
Marina Petrova Marcheva* \\ Department of Plant Genetic and Plant Breeding, Faculty of Agronomy, Agrarian University, Plovdiv, Bulgaria
}

\section{A B S T R A C T}

\begin{abstract}
The increasing interest in Camelina sativa over the last decade has been provoked by its various applications as sources of biodiesel, edible oil or fodder. Evaluation of morphological traits and productive potential of some plant genetic resources of the ex situ collection of the National gene bank of Bulgaria has been presented. Field trials of three cultivars with different origins and one local landrace in three succeeding years on two different soil types were conducted. Vegetation period of all accessions were short - up to 80 days. They had good lodging resistance, but serious shattering of pods, resulting in significant losses of grain. The poor nutrition regime was another reason for the low grain yields - up to $745 \mathrm{~kg} \mathrm{ha}^{-1}$ variety Roye (Poland). The oil content of camelina seed reach 38.8 percent. With average seed yield of $745 \mathrm{~kg} \mathrm{ha}^{-1}$ at $7.5 \%$ seed moisture the productive potential for oil yield of Roye is $289.2 \mathrm{I}$ ha ${ }^{-1}$. The analyses of fatty acid composition of evaluated Camelina sativa accessions differ from the reported results for other researches. Highest composition is detected for MFA - oleic acid - 25.9\% (the local landrace), Polland variety Sortadinskiy produces maximum $19.1 \%$ eicosenoic acid, Erucic acid varies strongly - $0.4 \%$ (Hoga) and $0.5 \%$ (Bulgarian landrace) up to $5.3 \%$ of the oil content (Polland varieties). Polyunsaturated fatty acids have a smaller percent of the total acid composition then other researchers report. Linoleic acid reached maximum $18.5 \%$ in the local landrace. The content of eicosadienoic acid is around $1.3-1.4 \%$ in the seeds of all camelina accessions. From the saturated fatty acids major component in camelina seed is palmitic acid - $12.5 \%$ (Sortadinskiy), followed by stearic acid - up to $4.2 \%$ (Sortadinskiy). Successful cultivation of Camelina sativa in Bulgaria could be achieved after improvement of nutrition regime by mineral or organic fertilization, optimization of practices for prevention of the shattering of seed pods and losses of great amounts of seeds by appropriate date and harvest machinery or breeding new varieties with better shattering resistance and harder pods' shell.
\end{abstract}

Keywords: Biodiesel; Camelina; Evaluation; Fatty acids; Plant genetic resources

\section{INTRODUCTION}

Camelina sativa has regained interest as an attractive crop because of its good adaptation to various environmental conditions - soil type and fertility, water regime, temperature, low requirements to fertilization and pesticeds (Crowley and Frohlich, 1998; Fleenor, 2011; Piernicola et al., 2014). It has various applications as feedstock for biodiesel, technical or edible oil and fodder. Camelina oil contained high percentages of linolenic (32.6 wt $\%$ ), linoleic $(19.6 \mathrm{wt} \%)$, and oleic (18.6 wt\%) acids. Consequently, camelina oil methyl and ethyl esters (CSME and SEE) exhibited poor oxidative stabilities and high iodine values versus methyl esters prepared from canola, palm, and soybean oils (CME, PME, and SME). As blend components in ultra-low sulfur diesel fuel, CSME and CSEE were essentially indistinguishable from SME and soybean oil ethyl ester blends with regard to low temperature operability, kinematic viscosity, lubricity, and surface tension (Frohlich and Rice, 2005). Given these features, $C$. sativa will not displace or compete with other food-crops and will not affect food supply.

The by - products from oil extraction are similar to soybean and canola meat and contain more than $40 \%$ proteins and have a moderately - low glucosinolate content. They can be used in heifer, chick, pig and fish feeding. In Europe camelina is been marketed in salad dressing, cooking oil (not suitable for deep-fat fry oil). It is also used in cosmetics, skin care products, soaps and soft detergents. Camelina

\section{*Corresponding author:}

Marina Petrova Marcheva, Plant genetic and Plant breeding dept/ Faculty of Agronomy/ Agrarian University/ Plovdiv/ Bulgaria,

E-mail: marina.marcheva@gmail.com 
performs well as a companion crop in establishing legumes for green manure cover and for forage (Hunter, 2010).

Despite this potential, there are few camelina varieties that have been genetically improved and genetic and genomic characterization of camelina is still lagging behind (Hrastar et al., 2012). It has been proved that transgenic Camelina sativa can produce omega - 3 long chain polyunsaturated fatty acids (n-3 LC-PUFA), widely recognized as functional food for prevention of cardiovascular disease and related metabolic conditions and primary found in fish oils, without any impact of the total seed oil as a stable trait in field conditions (Usher et al., 2015). The eicosapentaenoic acid oil from transgenic Camelina (ECO) could be used as a substitute for fish oil, however it is a hybrid oil containing both fish oil and vegetable oil (18:2 n-6) fatty acid signatures that resulted in similarly mixed metabolic and physiological responses. In addition, wild-type camelina is naturally rich in $\alpha$ linolenic acid (ALA 18: $3 \mathrm{n}-3$ ) ( 45\%) (Betancor et al., 2015), the substrate fatty acid for the biosynthesis of $n-3$ LC-PUFA.

Molecular markers for genetic characterization in camelina, has been published by Vollmann et al. (2005) - RAPD, Ghamkhar et al. (2010) - ALFP and Manca et al. (2013) SSR. Besides providing a useful tool for germplasm identification and genetic diversity they will be useful in genetic mapping and assisting plant breeders in early progeny selection.

\section{MATERIALS AND METHODS}

To evaluate the expression of the genetic potential of different accessions of Camelina sativa (L.) Crantz from the ex situ collection of the National genebank of Bulgaria in IPGR Sadovo, two spring-seeded trials were conducted on two sites with different soil types - Chromic Luvisol and Fluvisol - in three years from 2008 to 2010.

The evaluation of three varieties - Sortadinskiy (Poland), Hoga (Netherlands), Roye (Poland) and one local landrace from Bulgaria have been conducted on basic field conditions - natural soil fertility with minimal cultivation inputs. Experiments were arranged as lattice designs in two replicas on $10 \mathrm{~m}^{2}$ plots. The trials were sown in March following the wheat crop. Seeding rates were $4 \mathrm{~kg}$ of pure, live seeds per hectare. No fertilization was used as well as treatment with any pesticides. Harvesting in the beginning of June was conducted by standard plot combine directly without desiccation. Morphological and agronomical traits were determined on 30 plants from each variant and replication - PH (plant height, $\mathrm{cm}$ ); H 1 (height to the first branch, cm); NB (number of branches), NP (number of pods per plant), LP (length of pod, cm); WP (width of pod, cm); LW ratio; SP (number of seeds per pod), W1000 (weight of 1000 seeds, g); WS (weight of seeds in one plant, g); seed yield $\left(\mathrm{kg} \mathrm{ha}^{-1}\right)$, Seed moisture (\%); Oil content $(\%)$; Oil yield $\left(1 \mathrm{ha}^{-1}\right)$. Adjusted entry means from the lattice analysis were used for the combined analyses of variance, LSI (least significant increase, one-tailed t-statistic) was used as a statistical testing procedure (Petersen, 1994).

Determination of oil content was performed in the Department of Chemical Technology, Plovdiv University. The seeds (20 g sample) were air-dried (10\% humidity). Camelina oil was extracted from finely ground seeds with hexane in a Soxhlet apparatus for $8 \mathrm{~h}$. After extraction the solvent was removed in a rotary vacuum evaporator and the oil was determined by weight. Fatty acid composition of triacylglycerols and sterol esters was determined by gas chromatography (GC) of fatty acid methyl esters (FAME) (ISO 5508 (1990)).

\section{RESULTS AND DISCUSSION}

\section{Climate and soil conditions}

The evaluation of Camelina sativa accessions is made in the Institute of Plant Genetic Resources (IPGR) - Sadovo. The accessions in ex situ collection are characterized and evaluated in field conditions in experimental plots of $10 \mathrm{~m}^{2}$. The experimental field is located in the Thracian Plain of South Central Bulgaria at $141 \mathrm{~m}$ asl, $42^{\circ} 07^{\prime} \mathrm{N}$ and $24^{0} 56^{\circ} \mathrm{E}$. The climate is trans-continental with hot and dry summer and critical drought period in spring. Average annual rainfall around $345 \mathrm{ml} / \mathrm{m}^{2}$, unevenly distributed in crop vegetation, high summer temperatures (up to $38^{\circ} \mathrm{C}$ ) and cold winters without snow cover are typical for the region. High air temperature accompanied by low air humidity and winds are observed in the end of May and June and often cause extreme and rapid drying of seeds and plants in the last vegetation period (Uzundzhalieva, 2014).

The Botanical garden is located on Chromic Luvisol (by FAO) - sandy loam with moderate humus horizon and low humus content. The soil $\mathrm{pH}$ reaction is acid to poor acid. The soil reserve of mobile phosphorus and acid hydrolysable mineral nitrogen is poor and good for mobile potassium. Mobile manganese, copper and zinc are sufficient but molybdenum supply is unfavorable. The experimental field is situated on Fluvisol (by FAO) with poor humus horizon, characterized with light mechanical structure and low moisture preservation ability. A moderate to low humus content and neutral soil $\mathrm{pH}$ reaction with good reserve of mobile potassium, moderate to low content of mobile phosphorus and very low nitrogen supply has been determined (Koinov et al., 1998). 


\section{Agronomical performance}

In the conditions of Southeastern Bulgaria Camelina sativa has a very short vegetation period - 75 to 80 days. Sown in March, the accession flowers simultaneously in the beginning of May and reach maturity in early June. Camelina is used an annual crop from the mustard family with similar but tenderer appearance and aroma then canola. The plant grows up to a height from $47 \mathrm{~cm}$ (Sortadinskiy) to $81 \mathrm{~cm}$ (Hoga) (Table 1). The stems are single, usually branched above, glabrous, sometimes with few simple and branched hairs. The leaves are alternate, sessile, lanceolate, entire (Roye) or slightly (Hoga) toothed, sparsely hairy. The inflorescences are elongated racemes borne on ascending pedicels. The flowers are tetramerous, light yellow in colour. Each plant forms 36 (Sortadinskiy) to 177 (Roye) pods which are leathery, pear-shaped and contain many seeds (up to 17 in the local landrace) that are oblong, brown, deeply grooved and 2-3 mm long (Table 1 at the end).
Variety Sortadinskiy (Poland) is highly variable in different years and soil conditions. Its steam is relatively shorter $(63 \mathrm{~cm})$ and forms the first branches at $32 \mathrm{~cm}$ above the soil surface which is comfortable for mechanical harvesting. The plants have lowest number of branches, pods and number of seeds per pod. The seeds are also small with an average of 1000 seed weight 1.94 grams.

The Netherlands' variety Hoga is the tallest one in our conditions but no logging was observed. Its height is relatively stable in various environmental conditions (78 to $81 \mathrm{~cm}$ ). The first branch is settled up on $45 \mathrm{~cm}$. The plant is branched and forms around 100 pods with $11-13$ seeds. The accession has the biggest seeds with average 1000 seed weight from 3.44 up to 5.6 gram in 2010.

Serious shattering of the pods was observed every year and they were significant yield losses. The collected seeds per plant were smaller than the other accessions and did not exceed $1.6 \mathrm{~g}$ (average $1 \mathrm{~g}$ ).

\section{Table 1: Morphological characteristics of Camelina sativa accessions, evaluated in IPGR Sadovo in 2008 to 2010}

\begin{tabular}{|c|c|c|c|c|c|c|c|c|c|c|c|}
\hline Variety & Soil & $\mathrm{PH}$ & HB & NB & NP & LP & WP & L:W & SP & W1000 & WS \\
\hline \multicolumn{12}{|c|}{ Sortadinskiy } \\
\hline \multirow[t]{2}{*}{2008} & CL & 47,46 & 21,1 & 7,8 & 79 & 6,2 & 3,4 & 1,82 & 12,2 & 3,4 & 1,51 \\
\hline & $\mathrm{F}$ & 51,25 & 26,5 & 5,5 & 73,25 & 7 & 4,75 & 1,47 & 12,5 & 1,2 & 0,78 \\
\hline \multirow[t]{2}{*}{2009} & $\mathrm{CL}$ & 68 & 34,11 & 7,78 & 123,45 & 6,4 & 4,5 & 1,42 & 13,71 & 1,2 & 0,8 \\
\hline & $\mathrm{F}$ & 72,5 & 33,29 & 7,25 & 57,18 & 6 & 4,2 & 1,43 & 10,38 & 3,26 & 1,83 \\
\hline \multirow[t]{2}{*}{2010} & $\mathrm{CL}$ & 73,1 & 32,8 & 7,7 & 36,2 & 5,8 & 3,6 & 1,61 & 11,1 & 1,4 & 1,42 \\
\hline & $\mathrm{F}$ & 66 & 44,1 & 5,3 & 85,5 & 5,9 & 3,9 & 1,51 & 13,7 & 1,2 & 0,66 \\
\hline $\bar{x}$ & & 63,05 & 31,98 & 6,89 & 75,76 & 6,22 & 4,06 & 1,55 & 12,27 & 1,94 & 1,16 \\
\hline \multicolumn{12}{|l|}{ Hoga } \\
\hline \multirow[t]{2}{*}{2008} & $\mathrm{CL}$ & 79,2 & 45,7 & 7,7 & 108,5 & 6,1 & 4 & 1,53 & 12 & 4,8 & 1,6 \\
\hline & $\mathrm{F}$ & 80,1 & 44,8 & 7,5 & 98,1 & 6 & 3,7 & 1,62 & 12,3 & 5 & 1,2 \\
\hline \multirow[t]{2}{*}{2009} & $\mathrm{CL}$ & 80,2 & 44,7 & 8,7 & 118,1 & 5,8 & 4,1 & 1,41 & 11,9 & 4,8 & 0,76 \\
\hline & $\mathrm{F}$ & 79,3 & 44,4 & 8,8 & 96,9 & 6,1 & 4,4 & 1,39 & 12,1 & 3,44 & 1,15 \\
\hline \multirow[t]{2}{*}{2010} & $\mathrm{CL}$ & 81,3 & 46,6 & 5 & 41,1 & 6,3 & 3,7 & 1,7 & 12,8 & 4 & 1,11 \\
\hline & $\mathrm{F}$ & 78,1 & 44,4 & 4,6 & 121,2 & 6,7 & 3,7 & 1,81 & 13 & 5,6 & 0,65 \\
\hline $\bar{x}$ & & 79,7 & 45,1 & 7,05 & 97,32 & 6,17 & 3,93 & 1,58 & 12,35 & 4,61 & 1,08 \\
\hline \multicolumn{12}{|l|}{ Roye } \\
\hline \multirow[t]{2}{*}{2008} & CL & 64,3 & 32,5 & 8,1 & 82,3 & 6 & 4,1 & 1,46 & 14,7 & 3,4 & 1,7 \\
\hline & $\mathrm{F}$ & 66,7 & 33,1 & 8,5 & 71,5 & 5,9 & 4,1 & 1,44 & 13,9 & 2,9 & 1,56 \\
\hline \multirow[t]{2}{*}{2009} & $\mathrm{CL}$ & 63,9 & 30,6 & 8,2 & 68,6 & 6,1 & 4,2 & 1,45 & 15,1 & 0,8 & 0,34 \\
\hline & $\mathrm{F}$ & 68,5 & 33,8 & 9,4 & 86,8 & 5,8 & 4,1 & 1,41 & 14,2 & 3,68 & 1,37 \\
\hline \multirow[t]{2}{*}{2010} & $\mathrm{CL}$ & 69,8 & 33,7 & 7,6 & 39,2 & 6,9 & 3,8 & 1,82 & 13,7 & 0,8 & 2,2 \\
\hline & $\mathrm{F}$ & 69,3 & 34,6 & 8,1 & 177,6 & 7 & 3,5 & 2 & 14,9 & 0,8 & 1,68 \\
\hline $\bar{x}$ & & 67,08 & 33,05 & 8,32 & 87,67 & 6,28 & 3,97 & 1,6 & 14,42 & 2,06 & 1,48 \\
\hline \multicolumn{12}{|c|}{ Local landrace } \\
\hline \multirow[t]{2}{*}{2008} & $\mathrm{CL}$ & 65,7 & 34,5 & 8 & 80,3 & 6 & 4,2 & 1,43 & 16,2 & 1,7 & 1,9 \\
\hline & $\mathrm{F}$ & 68,3 & 32,1 & 8,1 & 78,6 & 5,9 & 4,3 & 1,37 & 15,1 & 2,5 & 2,12 \\
\hline \multirow[t]{2}{*}{2009} & $\mathrm{CL}$ & 63,4 & 30,4 & 8 & 69,2 & 6 & 4,2 & 1,43 & 14,7 & 1,5 & 1,1 \\
\hline & $\mathrm{F}$ & 65,5 & 32,5 & 8,4 & 88,3 & 5,9 & 4,2 & 1,4 & 15,9 & 2,1 & 1,4 \\
\hline \multirow[t]{2}{*}{2010} & $\mathrm{CL}$ & 69,2 & 34,1 & 8,6 & 67,8 & 6,7 & 3,9 & 1,72 & 16,8 & 1,9 & 2,5 \\
\hline & $\mathrm{F}$ & 67,8 & 35,2 & 8,6 & 88,6 & 6,9 & 3,9 & 1,77 & 15,1 & 2 & 1,98 \\
\hline $\bar{x}$ & & 66,65 & 33,13 & 8,28 & 78,8 & 6,23 & 4,12 & 1,52 & 15,63 & 1,95 & 1,83 \\
\hline
\end{tabular}

Legend: PH: Plant height, cm; H 1: Height to the first branch, cm; NB: Number of branches, NP: Number of pods, LP: Length of pod, cm; WP: Width of pod, cm; SP: Number of seeds per pod, W 1000: Weight of 1000 seeds, g; W S: Weight of seeds in one plant, g 
Relatively high $(67 \mathrm{~cm})$ and stable in our conditions is variety Roye (Poland). It is suitable for mechanic harvesting with around 8 branches, the first of which branches above $33 \mathrm{~cm}$. The total number of pods can reach 177 per plant, each of which has around 14 seeds with 1000 seeds weight up to $3.68 \mathrm{~g}$ (average $2 \mathrm{~g}$ ).

The local landrace from Bulgaria is the most stable genotype in the experiment. The plant is medium high $(65$ to $71 \mathrm{~cm}$ ) with first branches formed on $30-35 \mathrm{~cm}$ above the surface. It has around 8 branches per plant and can reach total of 88 pods with $10-16$ seeds per pod. The 1000 seeds weight is average -1.1 to 2.5 grams and the plant productivity can reach 2.50 grams.

Harvesting with standard plot combine directly without desiccation at seed moisture below 8 percent was performed in early June. Mean values of the results for seed and oil yields per hectare for each accession from all years and replica are presented on Table 2. Significant losses of seed yield in all plots and genotypes have been observed because of the serious shattering of pods. Camelina plant has moderate to low requirements for mineral fertilizing. Depending on the soil fertility, residual level of nutrients, weather conditions, etc., optimum nitrogen supply is about $100 \mathrm{~kg} / \mathrm{ha}$. About $30 \mathrm{~kg}$ phosphorous and $50 \mathrm{~kg}$ potassium per hectare should be provided (Zubr, 1997). Obviously the absence of mineral fertilizers in the experimental field for evaluation of plant genetic resources in Sadovo and none cultivation practices as treatments with pesticides has result in lower yielding capacity which is much below the reported camelina achievements in other countries (Frohlich and Rice, 2005; Hunter and Roth, 2010). From winter varieties, tested in Denmark, yields of $3300 \mathrm{~kg}$ per ha have been achieved. Unfavorable weather and diseases can alter also the productivity. The spring varieties in the same conditions reached yields of $2600 \mathrm{~kg}$ per hectare (Zubr, 1997).

At the natural minimal nutrition soil supply of our field better performance is observed in variety Roye (Poland) - $745 \mathrm{~kg} \mathrm{ha}^{-1}$ and the local landrace (Bulgaria) $680 \mathrm{~kg} \mathrm{ha}^{-1}$. Variety Hoga (Netherlands) has the biggest genetic potential for seed yield but major part of the seeds cannot be collected because of the serious shattering of

Table 2: Seed and oil yield of Camelina sativa accessions, evaluated in IPGR Sadovo in 2008 to 2010

\begin{tabular}{llcccc}
\hline Variety & Origin & $\begin{array}{c}\text { Seed } \\
\text { yield, } \\
\text { kg ha }^{-1}\end{array}$ & $\begin{array}{c}\text { Seed } \\
\text { moisture, } \\
\%\end{array}$ & $\begin{array}{c}\text { Oil } \\
\text { content, } \\
\%\end{array}$ & $\begin{array}{c}\text { Oil yield, } \\
\text { I ha }\end{array}$ \\
\hline Sortadinskiy & Poland & 674.0 & 7.8 & 36.0 & 242.6 \\
Hoga & Netherlands & 510.0 & 8.0 & 33.1 & 168.8 \\
Roye & Poland & 745.0 & 7.5 & 38.8 & 289.1 \\
Local landrace & Bulgaria & 680.0 & 7.5 & 36.9 & 250.9 \\
\hline
\end{tabular}

pods and thus its yields do not exceed $510 \mathrm{~kg} \mathrm{ha}^{-1}$. As the safety guidelines call for camelina to be stored at no more than an eye-popping low 8 percent humidity all samples were harvested below these values. For safe storage 6 percent is ideal, while at 10 percent there is a possibility for spontaneous combustion.

The oil content of camelina seed in our conditions vary from 33.1 (Hoga) up to 38.8 percent (Roye) which is above the range reported in previous studies (Leonard, 1998; Moser and Vaught, 2010; Sawyer, 2008) but lower than the found $43 \%$ in Denmark winter varieties from Zubr (1997). With an average seed yield of $745 \mathrm{~kg} \mathrm{ha}^{-1}$ at $7.5 \%$ seed moisture the productive potential for oil yield of Roye in South Bulgaria is $289.21 \mathrm{ha}^{-1}$. The local landrace has similar results - at $36.9 \%$ of oil it can produce $250.9 \mathrm{l} \mathrm{ha}^{-1}$. Those results are acceptable considering the low cost and could be obtained in organic farming systems on poor or unusable fields, unappropriated for other crop cultivation.

Cultivation practices aiming better nutrition and prevention of the shattering of seed pods and losses of great amounts of seeds and oil by appropriate date and harvest machinery or breeding new varieties with better shattering resistance and harder pods' shell can result in much better achievements. Additional application of mineral fertilization even in small rates could significantly increase the yield of seeds and oil.

The analysis of fatty acid composition of evaluated Camelina sativa accessions differs from the reported results for other researches (Moser and Vaughn, 2010, Putnam, 1993). Camelina oil is characterized by high content of unsaturated fatty acids (about 80 percent) but still lower than the reported 90 percent from Zubr (1997). Contrary to the others findings (Zybr, 1997), showing predominance of $\alpha$ - linolenic acid (C18: $3 n-3)$, amounting to above 35 percent of the total fatty acids, in our experiment monounsaturated fatty acids (MFA) prevail in all tested genotypes (Table 3). Highest composition is detected for oleic acid (18:1). In the Bulgarian landrace its value reached $25.9 \%$. Similar data are found in Roye $(25.8 \%)$ and Sortadinskiy (25.6\%). The recorded values exceed Putnam (1993) and Moser and Vaught (2010) observations of $17-18.6 \%$. Contradictory results are also found for eicosenoic acid (C 20:1n - 9). The second MFA was in the range of Zubr's findings but was significantly higher in our camelina seeds then the reported by other authors (Putnam, 1993). The first Polland variety Sortadinskiy produces maximum $19.1 \%$ of it and the second one - Roye - has the smallest record $-17.2 \%$.

Erucic acid (C22:1) varies strongly and in Hoga and Bulgarian landrace it remain $0.4 \%$ and $0.5 \%$ but in the 


\begin{tabular}{|c|c|c|c|c|}
\hline \multirow{3}{*}{$\begin{array}{l}\text { Fatty acid } \\
\text { composition }\end{array}$} & \multicolumn{4}{|c|}{ Composition in Genotype/Origine, in \% } \\
\hline & Sortadinskiy & Hoga & Roye & Landrace \\
\hline & Polland & $\overline{\text { Netherland }}$ & Polland & Bulgaria \\
\hline C12:0 & 0.1 & 0.2 & 0.1 & 0.1 \\
\hline C14:0 & 0.3 & 0.3 & 0.3 & 0.3 \\
\hline C14:1 & 1.4 & 1 & 0.8 & 1.2 \\
\hline C16:0 & 12.5 & 11.2 & 11.7 & 12 \\
\hline $\mathrm{C} 16: 1$ & 0.3 & 0.3 & 0.2 & 0.3 \\
\hline C17:0 & 0.1 & 0.1 & 0.1 & 0.1 \\
\hline C18:0 & 4.2 & 3.7 & 4.1 & 4.1 \\
\hline C18:1 & 25.6 & 24.3 & 25.8 & 25.9 \\
\hline C18:2 & 15 & 18.4 & 16.8 & 18.5 \\
\hline C18:3 & 11.6 & 17.8 & 15.4 & 14.2 \\
\hline C20:0 & 2.3 & 2.4 & 1.8 & 2.1 \\
\hline C20:1 & 19.1 & 17.6 & 17.2 & 18.5 \\
\hline C20:2 & 1.3 & 1.3 & 1.4 & 1.3 \\
\hline C22:0 & 0.6 & 0.7 & 0.5 & 0.6 \\
\hline C22:1 & 5.3 & 0.4 & 3.6 & 0.5 \\
\hline C24:0 & 0.3 & 0.3 & 0.2 & 0.3 \\
\hline
\end{tabular}

Polland varieties is up to $5.3 \%$ of the oil content. Our results for variety Hoga 's erucic content differs from the reported values (3\%) of the same genotype in Ireland and Denmark (Frohlichm 2005; Zubr, 1997).

Polyunsaturated fatty acids (PFA) in camelina oil has been analyzed - linoleic (C 18:2), $\alpha$-linolenic (ALA) (C 18:3) and eicosadienoic acid (C 20:2). All evaluated accessions different by percent of the total PFA composition than other researchers report (Frohlich, 2005; Putnam, 1993). Linoleic acid was up to $18.5 \%$ in the Bulgarian landrace and $18.4 \%$ in variety $\operatorname{Hoga}(14-15 \%$ in previous publications). The Netherland`s variety also has a higher composition of ALA - 17.8\% but this is much lower compared with $31-38 \%$ found by Frohlich (2005), Moser and Vaught (2010), Putnam (1993) and Zubr (1997). The content of eicosadienoic acid is around $1.3-1.4 \%$ in the seeds of all camelina accessions.

From the saturated fatty acids the major component in our camelina seed is palmitic acid (C 16:0) with 11.2\% (Hoga) to $12.5 \%$ (Sortadinskiy). Frohlich (2005) reports much lower content of palmitic acid $(5.4 \%)$ of the same variety, tested in Ireland with a better nutrition regime, and smaller amount of stearic acid (C 18:0) - 2.6\% which in our experiment was $3.7 \%$. Similar results for behenic (C20:0) and arachidic (C 22:0) acids have been found.

\section{CONCLUSIONS}

In the conditions of Southeastern Bulgaria Camelina sativa has a very short vegetation period -75 to 80 days. The plants are medium high and harvesting with standard plot combine directly without desiccation is possible in the early June. Good resistance to logging has been observed, but very serious shattering of the pods at full maturity occurs in all variants. Camelina plant has moderate to low requirements for mineral fertilizing. At the provided minimal nutrition regime better performance is observed in variety Roye (Poland) $-745 \mathrm{~kg} \mathrm{ha}^{-1}$. Variety Hoga (Netherlands) has the biggest genetic potential for seed yield but a major part of the seeds cannot be collected because of the serious shattering of pods and thus its yields do not exceed $510 \mathrm{~kg} \mathrm{ha}^{-1}$. The oil content of camelina seed in our field is in the range of previous researches but below the maximal reported values and can reach 38.8 percent (Roye). With average seed yield of $745 \mathrm{~kg} \mathrm{ha}^{-1}$ at $7.5 \%$ seed moisture the productive potential for oil yield of Roye in our experiment is $289.21 \mathrm{ha}^{-1}$. The Bulgarian landrace has similar results - at $36.9 \%$ of oil it can produce $250.9 \mathrm{l} \mathrm{ha}^{-1}$. The analysis of fatty acid composition of evaluated Camelina sativa accessions differs from the reported results for other researches. Highest composition is detected for MFA - oleic acid - $25.9 \%$, followed by $19.1 \%$ for eicosenoic acid. Erucic acid content varies from $0.4 \%$ up to $5.3 \%$ of the oil content. Polyunsaturated fatty acids have smaller percent of the total acid composition then other researchers report. Linoleic acid reached maximum $18.5 \%$ in the Bulgarian landrace. The Netherland `s variety Hoga has also higher composition of ALA - 17.8\% but still it cannot be compared with the $31 \%$ bound by Putnam. The content of eicosadienoic acid is around $1.3-1.4 \%$ in the seeds of all camelina accessions. From the saturated fatty acids major component in camelina seed is palmitic acid with $12.5 \%$, followed by stearic acid by $4.2 \%$. Successful cultivation of Camelina sativa in Bulgaria could be achieved with the establishment of an appropriate system for improvement of the nutrition regime by mineral or organic fertilization, optimization of practices for prevention of the shattering of seed pods and losses of great amounts of seeds and oil with on time harvest with suitable machinery or breeding new varieties with better shattering resistance and harder pods' shell. Organic farming, especially on poor and difficult for cultivation areas, can use winter and spring varieties of Camelina sativa as an adequate substitute of the traditional crops. The smaller grain yields can be compensated with additional value of the products as functional food and fodder and oil, analogue to fish oil, or biodiesel for the farmer.

\section{REFERENCES}

British Standards Institute Staff. 1990. Animal and vegetable fat and oils - Analysis by gas chromatography of methyl esters of fatty acids. ISO 5508. B S I Standards, Washingtonville, NY.

Betancor, M. B., M. Sprague, O. Sayanova, P. Campbell and J. Napier. 2015. Evaluation of a high-EPA oil from transgenic Camelina 
sativa in feeds for Atlantic salmon (Salmo salar L.): Effects on tissue fatty acid composition, histology and gene expression. Aquaculture. 444: 1-12.

Crowley, J. G. and A. Frohlich. 1998. Factors affecting the composition and use of camelina. (End of Project Report No.7).

Fleenor, R. 2011. Plant Guide for Camelina (Camelina sativa). USDANatural Resources Conservation Service, Spokane, WA 99201.

Frohlich, A. and B. Rice, 2005. Evaluation of Camelina sativa oil as a feedstock for biodiesel production. Ind. Crops Prod. 21(1): 25-31.

Ghamkhar, K., J. Croser, N. Aryamanesh, M. Campbell, N. Kon'kova and C Francis. 2010. Camelina (Camelina sativa (L.) Crantz) as an alternative oilseed: Molecular and ecogeographic analyses. Genome. 53: 558-567.

Hrastar, R., H. Abramovič and I. J. Košir. 2012. In situ quality evaluation of Camelina sativa landrace. Eur. J. Lipid Sci. Technol. 114(3): 343-351.

Hunter, J. and G. Roth. 2010. Camelina Production and Potential in Pennsylvania, Agronomy Facts 72. College of Agricultural Sciences, Crop and Soil Sciences, Pennsylvania State University.

Koinov, V., I. Kabakchiev and K. Boneva. 1998. Atlas of the soils in Bulgaria, Zemizdat, Sofia.

Leonard, E.C. 1998. Camelina oil: A-linolenic source. Inform. 9: 830-838.

Manca, A., P. Pecchia, S. Mapelli, P. Masella and I. Galasso. 2012. Evaluation of genetic diversity in a Camelina sativa (L.) Crantz collection using microsatellite markers and biochemical traits. Genet. Resour. Crop. Evol. 60: 1223-1236. DOI: 10.1007/ s10722-012-9913-8.
Moser, B. and S. Vaughn. 2010. Evaluation of alkyl esters from Camelina sativa oil as biodiesel and as blend components in Ultra low-sulfur diesel fuel. Bioresour. Technol. 101: 646-653.

Petersen, R. G. 1994, Agricultural Field Experiments, Design and Analysis, Marcel Dekker, New York.

Piernicola, M., T. Martinelli and G. Incoronata. 2014. Agronomic evaluation and phenotypic plasticity of Camelina sativa growing in Lombardia, Italy. Crop Pasture Sci. 65: 453-460.

Putnam, D. H., J. T. Budin, L. A. Field and W. M. Breene. 1993. Camelina: A promising low-input oilseed. In: Janick, J. and J. E. Simon (Eds.), New Crops, Wiley, New York, Pp. 314-322.

Sawyer, K. 2008. Is there room for camelina? Biodiesel Mag. 5(7): 83-87.

Usher, S., R. Haslam, N. Ruiz-Lopez, O. Sayanova and J. Napier. 2015. Field trial evaluation of the accumulation of omega-3 long chain polyunsaturated fatty acids in transgenic Camelina sativa: Making fish. Metab. Eng. Commun. Available from: http://www. dx.doi.org/10.1016/j.meteno.2015.04.002i.

Uzundzhalieva, K. 2014. Conservation and management of plant genetic resources from cultural and wildlife in Bulgaria. Int. J. Technol. Enhanc. Emerg. Eng. Res. 2(4): 4-5.

Vollmann, J., H. Grausgruber, G. Stift, V. Dryzhyruk and T. Lelley. 2005. Genetic diversity in camelina germplasm as revealed by seed quality characteristics and RAPD polymorphism. Plant Breed. 124: 446-453.

Zubr, J. 1997. Oil seed crop: Camelina sativa. Ind. Crop Prod. 6(1997): 113-119. 